\title{
EL ESTILO DE LETIZIA GIANFORMAGGIO
}

\author{
Luigi Ferrajoli \\ Universidad de Camerino (Italia)
}

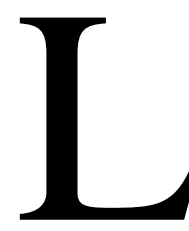

etizia Gianformaggio ha muerto serenamente de un terrible tumor que se reveló hace un año, manteniendo hasta el final su lucidez. Sobre la obra de esta extraordinaria estudiosa, sus importantes contribuciones a la filosofía y la teoría del Derecho, habrá que reflexionar en detalle, en ensayos y congresos dedicados a ella. Letizia ha sido, de hecho, una de las figuras de mayor relieve internacional en el panorama de la filosofía jurídica, de la filosofía moral y de la filosofía política. Basta pensar en sus innumerables trabajos sobre la argumentación jurídica, sobre la lógica del Derecho, sobre el análisis del lenguaje, sobre metaética, sobre la igualdad, sobre la diferencia y las diferencias, sobre la paz. Recuerdo, entre sus libros, Gli argomenti di Perelman: dalla neutralità dello scienziato all'imparzialità del giudice (Comunità); Diritto e felicità, La teoria del diritto in Helvétius (Comunità); Studi sulla giustificazione giuridica (Giappichelli); Etica e diritto. Le vie della giustificazione razionale (Laterza); Sistemi normativi statici e dinamici (Giappichelli); Le ragioni del garantismo (Giappichelli). Sin embargo, lo que me importa recordar de Letizia es, sobre todo, su gran lección de humanidad y de rigor civil y moral. Letizia había heredado de sus maestros, Norberto Bobbio y Uberto Scarpelli, el rasgo más importante y duradero de la filosofía analítica: la claridad de pensamiento; el valor de las distinciones; la inclinación a la duda; el rechazo de los lugares comunes, aunque estuvieran académicamente acreditados; el espíritu crítico; la concepción laica, racional, anti-ideológica y al mismo tiempo civilmente comprometida de la cultura y de la práctica jurídica. A este estilo intelectual añadía una cierta irónica modestia, en la que se expresaba la conciencia de los límites de nuestro trabajo, en aparente contraste con el sentido alto y severo del deber propio, sobre todo respecto de los jóvenes. Recuerdo siempre su intransigencia, en relación con los colegas, incluso los más competentes; la agudeza e inteligencia de sus críticas, tanto más eficaces en cuanto que desarrolladas con una claridad y simplicidad desarmantes; su compromiso militante, en los últimos años de su vida, con las organizaciones del voluntariado a favor de los inmigrantes. Esta simplicidad y esta serena fuerza de ánimo se ma- 
nifestaron de la manera más admirable en la actitud de Letizia frente a la muerte. En este último año de su vida, cuando ya era consciente de no tener ninguna esperanza de supervivencia, ninguno de los que hemos estado cerca le hemos visto jamás lamentarse. Incluso en los últimos días -la he visto por última vez hace algunos días, en el hospital, en Florencia- ha mantenido siempre un coraje extraordinario, como si se preocupase de nuestro dolor más que de su propia suerte.

No será posible llenar el vacío de afecto, además del de pensamiento, dejado por esta muerte prematura. Nos queda el ejemplo de una vida rica y generosa y un legado intelectual todavía en gran parte que repensar y valorar.

(Trad. de Daniel González Lagier) 